\title{
COMPARATIVE STUDIES ON THE GROWTH OF HIGH AND LOW VIRULENT STRAINS OF TOXOPLASMA GONDII, WITH SPECIAL REFERENCE TO THE PRODUCTION OF CYST*
}

\author{
ICHIRO NAKAYAMA and HISAKICHI MATSUBAYASHI \\ Department of Parasitology, School of Medicine, \\ Keio University, Tokyo
}

(Received for publication May 15, 1961)

Toxoplasma is an intracellular protozoa of which proliferative and cyst forms are recognized. Proliferative form is mainly seen during the acute infection and cyst form which is associated with the development of antibodies in the host is characteristic of chronic infection and it has a definite spherical cyst wall. It seems that the cyst form plays more important role than the proliferative form in regard to the transmission of Toxoplasma. As a part of observations on the development of cyst, an attempt was made to produce cyst with the highly virulent $\mathrm{RH}$ strain which usually kills the host animals in the acute infection and does not produce cyst. On the other hand an attempt was also made to investigate the proliferative form of the cyst-producing Beverley strain which usually develops a chronic infection, producing a large number of cysts in the brain of mouse inoculated.

\section{ON THE DEVELOPMENT OF CYST OF THE LOW VIRULENT STRAIN}

\section{Materials and Methods}

The Beverly strain was used. It has been maintained in mice by serial transplantations. Mice inoculated with this strain were sacrificed more than 3 weeks after the inoculation and their brains were put out. The emulsion was made of the brains added with $10 \mathrm{ml}$ sterile saline solution. Number of cysts contained in this emulsion was counted and 8-18 cysts, $0.3-0.5 \mathrm{ml}$ in amount of emulsion, were inoculated immediately in 5 normal mice and 5 splenectomized mice by intraperitoneal route. Those splenectomized mice had passed 17-59 days after splenectomy and were quite active. Intermittently from the 1st day

* The research reported in this document has been made possible through the support and sponsorship of the U. S. Department of Army, through its Far East Research Office. 
up to the 121th day after inoculation, abdominal fluids of these mice were obtained with a syringe and fresh smears of the fluid were examined under microscope to follow the appearance and disappearance of the proliferative forms. In some cases the abdominal fluid was examined by Giemsa stain. The brains of these mice which had did more than 3 weeks after inoculation were examined for the presence of cysts.

\section{Results}

1) Detection of the proliferative forms in the abdominal cavities of normal and splenectomized mice

Table 1

The appearance of proliferative forms in abdominal cavity of mouse inoculated with Beverley strain of Toxoplasma

(A) In the case of normal mice

\begin{tabular}{|c|c|c|c|c|c|c|c|c|c|c|c|c|c|c|c|c|c|c|}
\hline \multirow{2}{*}{$\begin{array}{l}\text { Number } \\
\text { of cyst } \\
\text { inoculated }\end{array}$} & \multirow{2}{*}{$\begin{array}{c}\text { Mice } \\
\text { no. } \\
\downarrow\end{array}$} & \multicolumn{16}{|c|}{ Days after inoculation } & \multirow{2}{*}{$\begin{array}{c}\text { Cyst in } \\
\text { brain after } \\
\text { died or } \\
\text { sacrificed }\end{array}$} \\
\hline & & 1 & 23 & $\begin{array}{l}34 \\
\end{array}$ & 5 & 6 & 7 & 8 & 910 & 11 & 121 & 1314 & 1415 & $16 \quad 17$ & $\begin{array}{lll}718 & 1\end{array}$ & 1920 & 21 & \\
\hline \multirow{10}{*}{8} & 1 & & & + & & & \# & & & + & & & \# & + & & - & & $\mathrm{m}$ \\
\hline & 2 & & & + & & & \# & & $+\mathrm{D}$ & & & & & & & & & \\
\hline & 3 & & & - & & & - & & & + & & & - & H & & - & D & - \\
\hline & 4 & & & - & & & + & & & + & & & + & - & & - & & \# \\
\hline & 5 & & & - & & & + & & & + & & & - & + & & - & & + \\
\hline & 6 & & & & - & & & + & & $+\mathrm{D}$ & & & & & & & & \\
\hline & 7 & & & & + & & & \# & & $H$ & & & + & H & & $-D$ & & + \\
\hline & 8 & & & & $H$ & & & \# & & + & & & $H$ & $\mathrm{D}$ & & & & \\
\hline & 9 & & & & - & & & \# & & $+\mathrm{D}$ & & & & & & & & \\
\hline & 10 & & & & + & & $+D$ & & & & & & & & & & & \\
\hline \multirow{10}{*}{10} & 11 & - & - & -+ & & + & & $\#$ & - & + & & - & - & & + & & - & \# \\
\hline & 12 & - & - & -+ & & - & & H & \# & - & & - & - & & $-\mathrm{D}$ & & & \\
\hline & 13 & - & - - & - & & + & & \# & + & + & & - & - & & - & & - & m \\
\hline & 14 & - & -- & -+ & & \# & & H & + & + & & - & -1 & $\mathrm{D}$ & & & & \\
\hline & 15 & -- & - & - - & & - & & + & - & + & & - & - & & - & & - & H \\
\hline & 16 & & - & & + & $\mathrm{D}$ & & & & & & & & & & & & \\
\hline & 17 & & - & & - & & - & & -- & & - & - & - & - & & - & - & H \\
\hline & 18 & & - & & - & & + & & $+H$ & & - & - & - & - & & - & - & H \\
\hline & 19 & & - & & - & & + & & $+H$ & $\mathrm{D}$ & & & & & & & & \\
\hline & 20 & & - & & $H$ & & \# & & ++ & D & & & & & & & & \\
\hline \multirow{5}{*}{18} & 21 & & -- & & + & & + & - & ++ & & - & & - & - & & & & Ht \\
\hline & 22 & & -- & & + & & m & HI H & & & & & & & & & & \\
\hline & 23 & & -- & - & + & & + & $\#$ & $H-$ & & - & & - & - & & & & $\mathrm{H}$ \\
\hline & 24 & & -- & & - & & + & - & -- & & - & & - & - & & & & m \\
\hline & 25 & & -- & & + & & $\mathrm{m}$ & + & +- & & + & - & - & D & & & & + \\
\hline
\end{tabular}

Day of inoculation $=$ day $\mathrm{O}, \mathrm{D}=$ death, $+=1 \sim$ several Tox. in a smear $(24 \times 18 \mathrm{~mm})$, $H=1 \sim$ several Tox. in several fields, $H=1 \sim$ several Tox. or more in one field. 
(B) In the case of splenectomized mice

\begin{tabular}{|c|c|c|c|c|c|c|c|c|c|c|c|c|c|c|c|c|c|c|c|c|c|}
\hline $\begin{array}{l}\text { Number } \\
\text { of cyst } \\
\text { inoculated }\end{array}$ & $\begin{array}{c}\text { Mice } \\
\text { no. } \\
\downarrow\end{array}$ & 1 & 2 & 3 & 4 & 5 & $\begin{array}{c}\text { Day } \\
6\end{array}$ & $\begin{array}{c}\text { ys a } \\
7\end{array}$ & $\begin{array}{r}\text { afte } \\
8\end{array}$ & $\begin{array}{r}\text { in } \\
9\end{array}$ & $\begin{array}{c}\text { nocu } \\
10\end{array}$ & $\begin{array}{l}\text { ulati } \\
11\end{array}$ & & 13 & & 151 & 161 & 1718 & 1920 & 21 & $\begin{array}{l}\text { Cyst in } \\
\text { brain after } \\
\text { died or } \\
\text { sacrificed }\end{array}$ \\
\hline \multirow{10}{*}{8} & 1 & & & & - & & & + & & & & + & & & - & & - & & - & & H \\
\hline & 2 & & & & + & & & HD & & & & & & & & & & & & & \\
\hline & 3 & & & & + & & & H & $H D$ & & & & & & & & & & & & \\
\hline & 4 & & & & - & & & - & & & & $H$ & & $+D$ & & & & & & & \\
\hline & 5 & & & & - & & & - & & & & - & & & - & & - & & - & & $\mathrm{H}$ \\
\hline & 6 & & & & & - & & & - & & & - & & & - & & - & & - & & $\mathrm{H}$ \\
\hline & 7 & & & & & + & & & \# & & & $+\mathrm{D}$ & & & & & & & & & \\
\hline & 8 & & & & & - & & & + & & & + & & & - & & - & & - & & $H$ \\
\hline & 9 & & & . & & - & & & - & & & - & & & + & & - & & - & & $\#$ \\
\hline & 10 & & & & & $\mathrm{D}$ & & & & & & & & & & & & & & & \\
\hline \multirow{10}{*}{10} & 11 & - & - & - & - & & + & & + & + & & + & & - & & - & & - & & - & + \\
\hline & 12 & - & - & + & - & & - & & H & + & & $\mathrm{D}$ & & & & & & & & & \\
\hline & 13 & - & - & - & - & & - & & m & + & & - & & - & . & - & & $-D$ & & & + \\
\hline & 14 & - & - & - & - & & - & & + & - & & $\mathrm{D}$ & & & & & & & & & \\
\hline & 15 & - & - & - & - & & - & & - & - & & + & & - & & - & & $-\cdots$ & & - & $H$ \\
\hline & 16 & & & + & & $H$ & & - & & - & - & & - & & + & & - & & - & - & + \\
\hline & 17 & & & + & $\mathrm{D}$ & & & & & & & & & & & & & & & & \\
\hline & 18 & & & - & & - & & - & & - & H & & + & & + & & + & & - & - & H \\
\hline & 19 & & & + & & + & & + & & + & + & & - & & - & & - & & - & - & + \\
\hline & 20 & & & - & & $+D$ & & & & & & & & & & & & & & & \\
\hline \multirow{5}{*}{18} & 21 & & - & - & & - & & - & $H$ & - & - & & - & & - & & & - & & & $H$ \\
\hline & 22 & & - & - & & - & & + & + & - & - & & - & & - & & & - & & & \# \\
\hline & 23 & & - & - & & - & & - & - & & $-\mathrm{D}$ & & & & & & & & & & \\
\hline & 24 & & - & - & & - & & + & + & - & - & & - & & - & & & - & & & $H$ \\
\hline & 25 & & - & - & & - & & - & - & - & - & & - & & - & & & - & & & H \\
\hline
\end{tabular}

(C) The number of mice from which the proliferative forms were found by the examination of the peritoneal fluid during the period 1-21 days after the inoculation.

\begin{tabular}{llrrrrrrrrrrrrrrrrrrrrrrrrr}
\hline $\begin{array}{l}\text { Days after } \\
\text { inoculation }\end{array}$ & & 1 & 2 & 3 & 4 & 5 & 6 & 7 & 8 & 9 & 10 & 11 & 12 & 13 & 14 & 15 & 16 & 17 & 18 & 19 & 20 & 21 \\
\hline $\begin{array}{l}\text { Normal } \\
\text { mice }\end{array}$ & exam. & 5 & 10 & 15 & 10 & 15 & 5 & 15 & 14 & 15 & 8 & 13 & 6 & 5 & 12 & 5 & 7 & 3 & 4 & 7 & 3 \\
\hline $\begin{array}{l}\text { Splenect. } \\
\text { mice }\end{array}$ & posit. & 0 & 0 & 0 & 5 & 9 & 3 & 13 & 12 & 11 & 4 & 12 & 1 & 0 & 4 & 0 & 4 & 0 & 1 & 0 & 0 \\
\hline
\end{tabular}

On the 1st and 2 nd day after the inoculation of cysts, the proliferative form was not detected in the abdominal cavities of mice. On the 3rd day, 4 of $\mathbf{1 5}$ splenectomized mice and on the 4th day, 5 of 10 normal mice were found to have the proliferative forms in their abdominal cavities. They were found most often on the $7,8,9$ and 11 th day and number of the proliferative forms in each mouse 
was maximum in those days both in normal and splenectomized mice. Thereafter they decreased in number gradually. In the cases of normal mice, they were found until 16th in 4 of 7 mice and until 18th day in 1 of 4 mice. Subsequent examinations made intermittently up to the 121 th day revealed no parasites. In the case of splenectomized mice, the results were almost the same with the normal mice: 1 of 8 mice was found to have the proliferative forms until the 16 th day, and no parasites were detected from the peritoneal fluid thereafter up to the 121th day (Table 1, A, B, C). Throughout those examinations, only the typical organisms in morphology were considered to be valied. Besides these typical organisms, smaller ovoid Toxoplasma-like bodies were found very often. These equivocal bodies were not taken for Toxoplasmas. These bodies, however, need further investigations.

There was no essential difference between the normal and splenectomized mice in the incidence of positive cases and in the number of proliferative forms appearing in the peritoneal fluid of positive mice.

Brains of mice which died or killed more than 20 days after the inoculation were examined for the presence of cyst. All mice except one were found to have had the cyst. The mouse from which the cyst was not detected was a normal

Table 2

The average size of proliferative forms appeared in the abdominal cavity after inoculation with Beverley strain

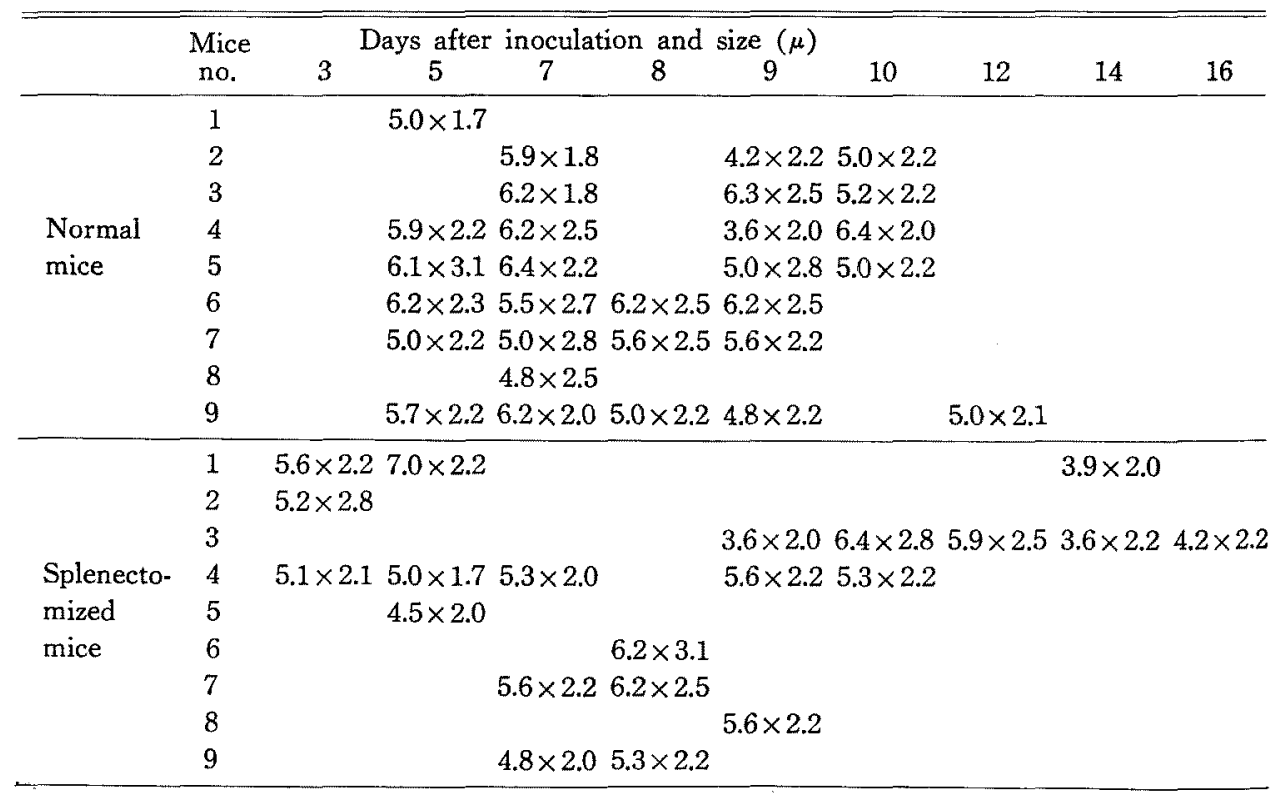


(not splenectomized) mouse and died 21 days after the inoculation. As the proliferative forms were found from its peritoneal fluid in two examinations made while it was alive, the cysts might have been produced in the brain, though they were not detected.

While the proliferative forms were present in the peritoneal cavity, normal saline was injected intra-peritoneally and was sucked up into the same syringe. This normal saline containing the proliferative forms were injected into clean mice of which the brains were examined after 3 weeks. All of these mice were found to have had cysts.

2) The size, length and breadth of proliferative forms

The sizes of proliferative forms were measured in the fresh smears of abdominal fluid of mice inoculated and those measurements have been made on the isolated extracellular organisms only. As the number of proliferative forms appeared in the abdominal cavity was usually small, the number of organisms measured from each mouse was also small, being one in some cases and the maximum was 41 . Table 2 indicates the average size.

There was no essential difference in size between the proliferative forms from normal mice and those from the splenectomized mice.

3) Infection experiments of mice with the proliferative forms of Beverley strain obtained from the abdominal cavity of mice which were previously inoculated with cysts of the same strain

When the proliferative froms were detected in the peritoneal fluid of mice inoculated with Beverley strain, the abdominal fluid was drawn and was inoculated in clean mice by intraperitoneal route and they were examined later for the production of cyst in their brains. To obtain those proliferative forms, $2.5 \mathrm{ml}$ of sterile saline solution was injected into abdominal cavities of the mice and the fluid was sucked up into the same syringe. $A$ half $\mathrm{ml}$ of this diluted abdominal fluid was inoculated immediately into 4-5 clean mice by intraperitoneal route. Those mice were sacrificed 3-4 weeks after inoculation and their brains were examined for the presence of cysts. After the disappearance of proliferative forms in the abdominal fluid, the same examinations were carried out intermittently 8 times between 23 and 121 days after inoculation.

So long as the proliferative forms were present in the abdominal fluid, all mice inoculated with the fluid had cysts in their brains when examined. Some of the instances are indicated in Table 3.

As mentioned previously, the proliferative forms disappeared from the peritoneal fluid 18 days after inoculation by the direct microspical examination. All peritoneal fluids drawn from 3 normal and 4 splenectomized mice on the 23rd 
Table 3

The detection of cyst in the brain of mouse which was subinoculated with abdominal fluid of mouse infected with Beverley strain.

\begin{tabular}{|c|c|c|c|c|c|c|c|c|c|c|}
\hline & \multirow{2}{*}{$\begin{array}{l}\text { Mice from } \\
\text { which the ab- } \\
\text { dominal fluid } \\
\text { was obtained }\end{array}$} & \multicolumn{3}{|c|}{ Days after the } & \multicolumn{3}{|c|}{ first inoculation with } & \multicolumn{2}{|c|}{ Beverley strain } & \multirow{2}{*}{121} \\
\hline & & 4 & 23 & 30 & 32 & 33 & 54 & 78 & 100 & \\
\hline \multirow{7}{*}{$\begin{array}{l}\text { Normal } \\
\text { mice }\end{array}$} & 1 & \#3/3 & & & & & & & & \\
\hline & 2 & $\# 2 / 2$ & & & & & & & & \\
\hline & 3 & & & $+1 / 3$ & & & & & & \\
\hline & 4 & & & $+2 / 3$ & & & & & & \\
\hline & 5 & & $+2 / 4$ & & & $-0 / 4$ & $-0 / 4$ & $-0 / 4$ & $-0 / 4$ & $-0 / 4$ \\
\hline & 6 & & $+1 / 4$ & & & $-0 / 4$ & $-0 / 4$ & $-0 / 2$ & $-0 / 4$ & $-0 / 4$ \\
\hline & 7 & & $+1 / 4$ & & & $+1 / 1$ & & & & \\
\hline \multirow{11}{*}{$\begin{array}{l}\text { Splenecto- } \\
\text { mized } \\
\text { mice }\end{array}$} & 1 & \#3/3 & & & & & & & & \\
\hline & 2 & \#1/1 & & & & & & & & \\
\hline & 3 & & & & $+1 / 3$ & & & & & \\
\hline & 4 & & & & $+2 / 5$ & & & & & \\
\hline & 5 & & & & \#3/4 & & & & & \\
\hline & 6 & & & $-0 / 2$ & & & & & & \\
\hline & 7 & & & $-0 / 3$ & & & & & & \\
\hline & 8 & & $+2 / 4$ & & & $-0 / 4$ & $-0 / 3$ & $+1 / 4$ & $-0 / 4$ & $-0 / 4$ \\
\hline & 9 & & $+2 / 4$ & & & $+1 / 4$ & $-0 / 4$ & $-0 / 4$ & $-0 / 4$ & $-0 / 4$ \\
\hline & 10 & & $+3 / 4$ & & & $+2 / 4$ & & & & \\
\hline & 11 & & $+2 / 4$ & & & $+1 / 4$ & & & & \\
\hline
\end{tabular}

$+=1 \sim$ several cysts in a smear $(24 \times 18 \mathrm{~mm})+=1 \sim$ several cysts in several fields, $\mathrm{H}=1 \sim$ several cysts or more in one or two fields.

The numerator indicates the positive mice and the denominator indicates the number of mice inoculated and examined.

day could produce cysts in 1 to 3 mice out of 4 inoculated (Table 3 ). The fluid obtained from 2 normal mice on the 30th day could produce cysts while inocula obtained on the same day from 2 splenectomized mice did not. Most of the materials obtained on the 32nd and 33rd day could produce cysts, while the materials obtained on the 54th day did not. Exceptionally, only one of the 4 inocula obtained on the 78th day produced cysts and the experiments carried out thereafter on the 100th and 121st day did not give positive results. There was no essential difference in the duration of the presence of parasites in the peritoneal fluid between the normal and splenectomized mice.

\section{ON THE CYST PRODUCTION FROM THE HIGH VIRULENT STRAIN Material and Methods}

The RH strain originally isolated by Sabin from a fetal 6 year old boy of Toxoplasmosis was used in these experiments. It has been maintained in mice by serial transplantations with 3-4 days interval and the mice inoculated died 
within 10 days after inoculation. To prolong the survival period of mice, pyridazine (3-Sulfanilamido-6-methoxypyridazine) suspension in water was given as a treatment. The drug was poured into the stomach by a soft vinyl-resin tube which was connected to an injection syringe with a needle. The needle was cut short near its root. The drug administration was begun a day before the inoculation of the $R H$ strain and was continued for 5-10 days, the doses varying from 4 to $50 \mathrm{mg}$ per day suspended in $0.5 \mathrm{ml}$ water. $\mathrm{RH}$ strain was inoculated by intraperitoneal route.

\section{Results}

1) Survival period of mice inoculated with $\mathrm{RH}$ strain and treated with pyridazine

The survival period of mice inoculated with $\mathrm{RH}$ strain and treated with pyridazine was remarkably prolonged (Table 4). Though the dosage of pyridazine varied from 4 to $50 \mathrm{mg}$ per day and the times of administration varied from 5 to 8 during a treatment, no essential difference was seen in the period of survival due to the difference in the daily doses or the times of administration of the drug. Only those mice receiving a daily dose of $4 \mathrm{mg}$ which ran 5 times often died of the infection: only 10 mice out of 70 of this group survived more than 3 weeks and 30 mice died of infection within 10 days.

The number of Toxoplasma inoculated varied from $10 \times 10^{4}-170 \times 10^{4}$. Those differences in the amount of inoculum did not materially influence the period of survival in this experiment. Consequently 38 of 142 mice survived 3 weeks or more by the treatment.

Table 4

The survival periods of mice which was given pyridazine orally after inoculation with RH strain.

\begin{tabular}{|c|c|c|c|c|c|c|c|c|}
\hline \multirow{2}{*}{$\begin{array}{c}\text { Dose per } \\
\text { day \& } \\
\text { times }\end{array}$} & \multirow{2}{*}{$\begin{array}{l}\text { Number of } \\
\text { Toxoplasmas } \\
\text { inoculated }\end{array}$} & \multirow{2}{*}{$\begin{array}{l}\text { Number } \\
\text { of mice }\end{array}$} & \multicolumn{6}{|c|}{$\begin{array}{c}\text { Days after inoculation and number } \\
\text { of mice survived }\end{array}$} \\
\hline & & & 5 & 7 & 10 & 14 & 17 & 21 \\
\hline $50 \mathrm{mg} \times 8$ & $100 \times 10^{4}$ & 4 & 4 & 4 & 3 & 3 & 2 & 1 \\
\hline $50 \mathrm{mg} \times 5$ & $150 \times 10^{4}$ & 10 & 6 & 6 & 6 & 5 & 5 & 5 \\
\hline $20 \mathrm{mg} \times 6$ & $40 \times 10^{4}$ & 12 & 11 & 11 & 10 & 9 & 7 & 5 \\
\hline $8 \mathrm{mg} \times 6$ & $40 \sim 170 \times 10^{4}$ & 32 & 28 & 22 & 20 & 13 & 13 & 11 \\
\hline $4 \mathrm{mg} \times 6$ & $10 \sim 95 \times 10^{4}$ & 14 & 14 & 11 & 9 & 9 & 7 & 6 \\
\hline $4 \mathrm{mg} \times 5$ & $10 \sim 145 \times 10^{4}$ & 70 & 67 & 39 & 26 & 18 & 16 & 10 \\
\hline \multicolumn{2}{|c|}{ Total } & 142 & 130 & 93 & 74 & 57 & 50 & 38 \\
\hline
\end{tabular}

2) The period of the appearance and the size of proliferative forms in the peritoneal cavity of mice inoculated with $\mathrm{RH}$ strain and treated with pyridazine 
Proliferative forms of $\mathrm{RH}$ strain appeared on the 2nd day after inoculation and they disappeared mostly within 9 days in 12 out of 13 mice which survived until 11 days after inoculation. The observation was not made on the 1st day. In one exceptional case, comparatively a large number of proliferative forms were detected from the 11th through the 15th day. They were not detected when examined on the 18th and 21st day and died on the 22nd day. In one case they appeared only on the 4 th and 15th day (Table 5). In 3 mice which died on the 6th day, proliferative forms were detected on the 2 nd and 4 th day.

Table 5

The appearance and the average size $(\mu)$ of $R H$ strain in abdominal cavities of mice treated with pyridazine. Doses varied 4-8 mg a day for 6 days. Number of parasiles inoculated was $40 \times 10^{4}-100 \times 10^{4}$.

\begin{tabular}{ccccccccc}
\hline \hline $\begin{array}{c}\text { Mice } \\
\text { No. }\end{array}$ & 2 & \multicolumn{9}{c}{ Day after inoculation } & 4 & 6 & 8 & 9 & 11 & 13 & 15 \\
\hline 1 & & - & - & - & & $6.1 \times 3.7$ & $6.2 \times 1.9$ & $6.2 \times 2.0$ \\
2 & & $5.8 \times 3.4$ & - & - & & - & - & $6.1 \times 2.0$ \\
3 & & $6.2 \times 3.9$ & $5.4 \times 2.6$ & $6.0 \times 1.8$ & & $-\mathrm{D}$ & & \\
4 & & $5.5 \times 3.3$ & $5.6 \times 1.7$ & $5.4 \times 1.8$ & & $-\mathrm{D}$ & & \\
5 & $6.7 \times 3.2$ & $6.1 \times 2.7$ & - & & $6.3 \times 3.1$ & $-\mathrm{D}$ & & \\
6 & $5.1 \times 2.4$ & $6.8 \times 3.1$ & $6.1 \times 2.9$ & & - & & & \\
7 & $6.2 \times 1.6$ & $7.7 \times 2.0$ & - & & - & & & \\
8 & $4.5 \times 1.9$ & $6.1 \times 3.3$ & - & & - & $\mathrm{D}$ & & \\
9 & $6.2 \times 2.0$ & $6.0 \times 1.6$ & $\mathrm{D}$ & & & & & \\
10 & $4.4 \times 2.0$ & $5.3 \times 4.9$ & $\mathrm{D}$ & & & & & \\
11 & $5.1 \times 1.7$ & $5.6 \times 4.4$ & $53 . \times 3.6$ & $6.0 \times 5.0$ & & - & & \\
12 & $5.8 \times 2.7$ & $5.3 \times 4.4$ & $+\mathrm{n} . \mathrm{m}$. & $6.4 \times 4.2$ & & - & & \\
13 & $5.4 \times 1.8$ & $4.1 \times 3.4$ & $+\mathrm{n} . \mathrm{m}$. & - & & - & & \\
14 & $5.8 \times 1.7$ & $6.5 \times 2.3$ & $\mathrm{D}$ & & & & & \\
15 & $5.7 \times 2.3$ & $4.5 \times 3.5$ & $+\mathrm{n} . \mathrm{m}$. & - & & - & & \\
16 & $+\mathrm{n} . \mathrm{m}$. & $6.4 \times 2.1$ & $7.5 \times 6.8$ & - & & - & & \\
17 & $5.6 \times 1.5$ & $+\mathrm{n} . \mathrm{m}$. & $5.6 \times 2.2$ & $-\mathrm{D}$ & & & & \\
\hline
\end{tabular}

-: No parasites, + n.m.: Appeared but not measured, D: Death

Their size was measured in the smears stained with Giemsa. Table 5 indicated the average size. The average length was almost normal, but the breadth in an average became much larger than normal in some cases.

For the comparison, size of $\mathrm{RH}$ strain in serial transplantations and not treated with pyridazine was measured with Giemsa stained 500 Toxoplasmas each on the 3 rd and 4 th day after inoculation. The average size of these normal Toxoplasma was $5.90 \mu \pm 0.02 \mu \times 1.76 \mu \pm 0.01_{\mu}$ on the $3 \mathrm{rd}$ day and $5.78 \mu \pm 0.02 \mu \times$ $1.95 \mu \pm 0.01 \mu$ on the 4 th day. On comparison with the breadth on the 3rd and 4th day, the former was a little smaller than the latter. The average total size of parasites on both days was $5.84 \mu \pm 0.01 \mu \times 1.85 \mu \pm 0.01 \mu$ (Table 6, Figs. 1, 2). 
Table 6

The size of extracellular proliferative form of $R H$ strain (Control)

\begin{tabular}{|c|c|c|c|c|c|c|c|}
\hline & \multirow[b]{2}{*}{$\operatorname{Size}(\mu)$} & \multicolumn{4}{|c|}{$\begin{array}{l}\text { After inoculation } \\
\text { ays }\end{array}$} & \\
\hline & & $\begin{array}{r}3 \\
\text { numb. }\end{array}$ & ys & $\begin{array}{c}4 \\
\text { numb. }\end{array}$ & ys $\%$ & numb. & $\%$ \\
\hline \multirow{7}{*}{ Length } & $3.6-4.0$ & 0 & 0 & 4 & 0.8 & 4 & 0.4 \\
\hline & $4.1-5.0$ & 21 & 4.2 & 33 & 6.6 & 54 & 5.4 \\
\hline & $5.1-6.0$ & 280 & 56.0 & 298 & 59.6 & 578 & 57.8 \\
\hline & $6.1-7.0$ & 185 & 37.0 & 154 & 30.8 & 339 & 33.9 \\
\hline & $7.1-8.0$ & 12 & 2.4 & 10 & 2.0 & 22 & 2.2 \\
\hline & $8.1-8.5$ & 2 & 0.4 & 1 & 0.2 & 3 & 0.3 \\
\hline & Average & \multicolumn{2}{|c|}{$5.90 \pm 0.02 \mu$} & \multicolumn{2}{|c|}{$5.78 \pm 0.02 \mu$} & \multicolumn{2}{|c|}{$5.84 \pm 0.01 \mu$} \\
\hline \multirow{7}{*}{ Width } & $0.9-1.0$ & 1 & 0.2 & 0 & 0 & 1 & 0.1 \\
\hline & $1.1-1.5$ & 165 & 33.0 & 73 & 14.6 & 238 & 23.8 \\
\hline & $1.6-2.0$ & 276 & 55.2 & 295 & 59.0 & 571 & 57.1 \\
\hline & $2.1-2.5$ & 36 & 7.2 & 72 & 14.4 & 108 & 10.8 \\
\hline & $2.6-3.0$ & 17 & 3.4 & 41 & 8.2 & 58 & 5.8 \\
\hline & $3.1-3.4$ & 5 & 1.0 & 19 & 3.8 & 24 & 2.4 \\
\hline & Average & \multicolumn{2}{|c|}{$1.76 \pm 0.01 \mu$} & \multicolumn{2}{|c|}{$1.95 \pm 0.01 \mu$} & \multicolumn{2}{|c|}{$1.85 \pm 0.01 \mu$} \\
\hline
\end{tabular}

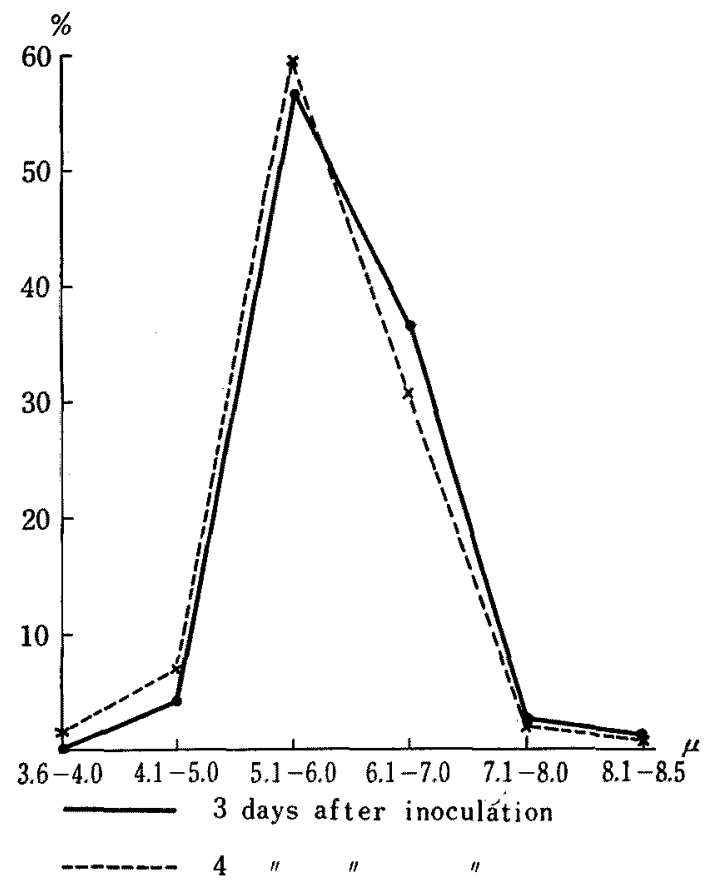

Fig. 1 The length of normal proliferative form of $\mathrm{RH}$ strain (measured 1000 Toxoplasmas in Giemsa strain). 


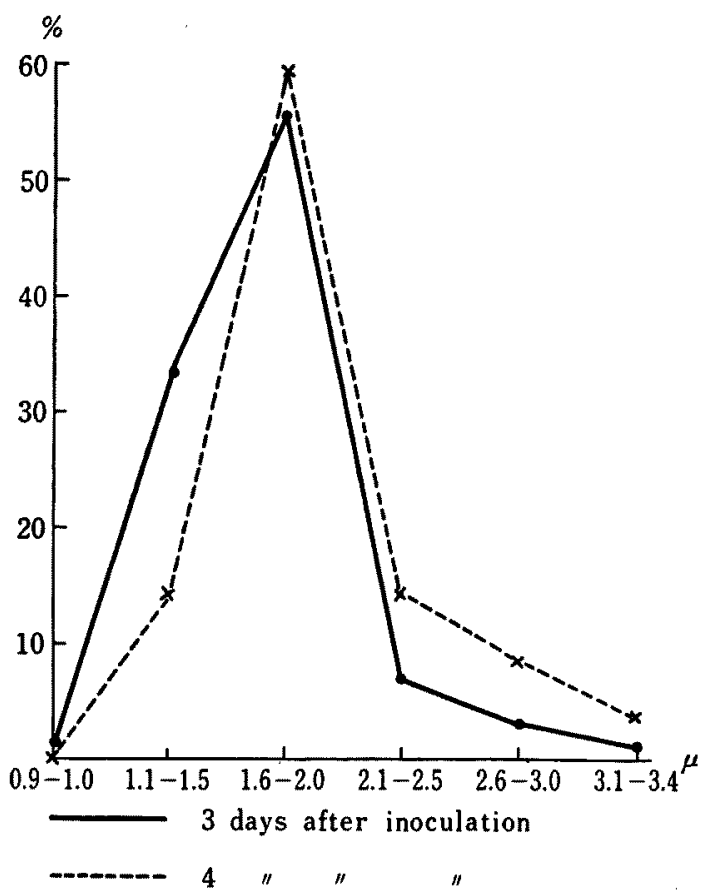

Fig. 2 The breadth of normal proliferative form of RH strain.

\section{3) Cyst of $\mathrm{RH}$ strain detected in brains of mice}

Twenty six mice, which survived the infection of $\mathrm{RH}$ strain for more than 20 days and up to 77 days after the inoculation of $\mathrm{RH}$ strain, were examined to detect the cysts in their brains. Cysts were demonstrated in the brains of 13 or one half of the mice by the examination of fresh as well as Giemsa stained smears. The number of cysts demonstrated was not always small and their maximum and minimum sizes were $36.6 \mu \times 33.2 \mu$ and $12.6 \mu \times 11.5_{\mu}$ respectively. A mouse which was given a daily dose of $4 \mathrm{mg}$ pyridazine for 6 days and inoculated with $80 \times 10^{4} \mathrm{RH}$ Toxoplasmas died on 29 days after inoculation. By the necropsy a large number of cysts and proliferative forms were found in its brain. The average size of these proliferative forms estimated from 100 organisms in Giemsa stained smears was $5.4 \mu \times 3.0 \mu$. The breadth of these organisms was also larger than normal.

The brains of 38 mice (including 26 mice listed on the table 7) which survived the RH infection for more than 20 days by the treatment with pyridazine were emulsified with normal saline and inoculated into clean mice, 3 mice each being inoculated with the emulsion of one brain. Each mice received 
Table 7

Number of mice in which cyst were demonstrated by the examination of smears of the brain after inoculation of RH strain and treatment with Pyridazine.

\begin{tabular}{lccc}
\hline \hline $\begin{array}{c}\text { Days after } \\
\text { inoculation }\end{array}$ & $\begin{array}{c}\text { Number of mice } \\
\text { examined }\end{array}$ & $\begin{array}{c}\text { Number of cyst- } \\
\text { positive mice }\end{array}$ & $\begin{array}{c}\text { RH infection after } \\
\text { subinoculation } \\
\text { with brain emulsion }\end{array}$ \\
\hline $20-25$ & 13 & 7 & $+(13)$ \\
$26-30$ & 8 & 4 & $+(8)$ \\
$31-77$ & 5 & 2 & $+(5)$ \\
\hline Total & 26 & 13 & \\
\hline
\end{tabular}

$0.5 \mathrm{ml}$ amount of the emulsion. All mice died of the acute toxoplasmosis, proliferative forms being demonstrated in their peritoneal fluid. The earliest appearance of these proliferative forms was on the 4 th day after the inoculation of the emulsion, just as was the case with the cysts of Beverley strain. Their survival was, however, a little longer than that of the mice in the routine subinoculation of the $\mathrm{RH}$ strain. The proliferative forms first appeared 7 days after the inoculation in many cases and it took another 4-5 days until mice died.

\section{DISCUSSION}

Proliferative form of Toxoplasma requires an intracellular situation in order to grow and multiply. During this period, antibodies are produced gradually in the host and the growth is suppressed by the action of antibodies and the proliferative form which has invaded into the viscera such as brain, spleen, liver, lung and muscle develops usually a chronic asymptomatic infection, producing a large number of cysts there. Toxoplasma can survive especially in brain for a long period. When the proliferation is so rapid that the antibody production can not be in time to suppress the growth of parasites before animals succumb to the infection, such strain is considered to be a high virulent strain. When antibodies produced can suppress the proliferation, this strain is considered as a low virulent strain. As the proliferation of Beverley strain in mice is slower than that of $\mathrm{RH}$ strain, the number of Toxoplasmas appearing in the peritoneal cavity is much smaller than in the latter. The maximum number of proliferative forms is usually attained on the period between 7 and 10 days after inoculation in the Beverley strain and the antibody production may begin in this period, suppressing the growth of Toxoplasmas which decrease gradually in number. The number and period of appearance of proliferative forms in peritoneal fluid were not related to the number of cysts inoculated, because no difference was 
recognized as to the above criteria by the inoculation between 8 and 18 cysts. Lainson (1958) inoculated avirulent strains into mice by intraperitoneal route and obtained similar results. According to him, following the intraperitoneal inoculation of mice with 11 avirulent strains of Toxoplasma, the parasites showed only a poor growth within the cells of the peritoneal fluid. Toxoplasmas here were always very scanty, attaining a maximum number on about the 6th day of infection. After this time the number dwindled until no parasites could be found in this site approximately 14 days after the inoculation. As compared with the infection of high virulent strains, the division of the parasites seemed to be much slower and only a small number of parasites were seen in any one cell, usually less than 20 .

In the cases of Beverley cysts inoculation, the first appearance of proliferative forms in abdominal cavity was on the 4 th day after the inoculation in 4 of 10 normal mice and on the 3rd day in 4 of 15 splenectomized mice and before these days no parasite was detected. Those findings were almost similar to the cases of inoculation with the cysts of $\mathrm{RH}$ strain, and the appearance of proliferative forms was much slower than the inoculation with the proliferative forms of the same strain. It is considered that a certain lapse of time was necessary before the proliferative forms burst from the cyst and invade the cells in the peritoneal fluid to begin the growth by binary division.

As to the size of proliferative forms, the breadth of low virulent Beverley strain seemed to be a little larger than that of the high virulent $\mathrm{RH}$ strain. When pyridazine was given to mice inoculated with $\mathrm{RH}$ strain to produce cysts, the proliferative forms appearing in abdominal cavity became larger in breadth.

When cysts of Beverley strain were inoculated into mice, proliferative forms appear in the peritoneal cavity in the period extending from the 4 th to 18th day after the inoculation. No parasites could be detected microscopically thereafter even by the repeated close examinations of the fluid. When the fluid from which the parasites had disappeared was inoculated into clean mice, cyst were produced very often in the brain. Thus the fluid drawn 33 days after inoculation could produce cysts very often in the mice inoculated. This was the longest period during which the parasites could be demonstrated in the peritoneal fluid by animal inoculations, though in an exceptional case the parasites were demonstrated 78 days after the inoculation in splenectomized mice. Lainson (1958) also could not find parasites microscopically from the peritoneal fluid of mice inoculated with Beverley strain when more than 2 weeks had passed after the inoculation. It is clear from these observations that the typical proliferative forms hardly been detected from the peritoneal fluid in the 
period later than 2-3 weeks after the inoculation of Beverley strain, yet the fluid must contain some organisms which produces cysts when inoculated into mice. The organisms may be the typical proliferative forms which being quite few in number, may be overlooked by the microscopical examinations. The organisms, on the other hand, might undergo some morphological modification in those later stages of infection. Actually, some Toxoplasma-like organisms were often discovered in fresh smears. They were smaller in size, measuring $2.5 \mu-3.6 \mu$ in length and $1.3 \mu-2.2_{\mu}$ in breadth. It was not possible to determine whether they were Toxoplasma or not. Further observations on these bodies are necessary.

Jacobs (1953) found no evidence that splenectomized mice were more susceptible to infection with the avirulent strain 113 than are controls. Throughout the present experiments there was no essential difference in the susceptibility to Toxoplasma between normal and splenectomized mice.

To produce cysts of $\mathrm{RH}$ strain in brains of mice, pyridazine was given to mice inoculated and cysts were found in one half of mice examined. Besides, all brain emulsions of mice which survived the infection by pyridazine treatment more than 20 days after inoculation of $\mathrm{RH}$ strain, developed acute infection when inoculated into clean mice by intraperitoneal route. All mice succumbed to the acute toxoplasmosis, as revealed by a large number of proliferative forms in their abdominal cavities. Accordingly, it may be concluded that cysts were produced in the brains of all mice inoculated though in some cases they were not detected by close microscopical examinations. Pyridazine treatment in the doses stated above suppressed the acute infection, but did not eradicate the parasites.

According to Frenkel $(1953,1956)$, animals which survived the acute infection usually remain chronically infected, although a fairly effective degree of immunity can be shown to exist. He could easily demonstrate this kind of infection in toxoplasmosis of mice after a brief period of partially suppressive chemotherapy: chronic infections with $\mathrm{RH}$ strain could be produced in 48 per cent of mice by intermittent treatment using $\mathrm{Na}$-Sulfadiazine and Na-Sulfamerazine for 63 days over a period of 85 days. All $\mathrm{RH}$-injected mice receiving the large inocula died after cessation of treatment and following prolonged incubation periods, whenever they were infected. He also demonstrated the typical cyst of RH strain in fresh preparation from the brain of a mouse, as well as the definite cyst wall in the silver impregnated specimens approximately one year after infection.

When the RH infections were treated with pyridazine, the proliferative forms appeared and disappeared in the peritoneal fluid in the similar stage 
of infection as in the cases of Beverley strain infection. No essential differences could be demonstrated as to the biological characteristics between these low and high virulent strains.

\section{SUMMARY}

High virulent $R H$ strain and the lower virulent Beverley strain of Toxoplasma gondii were used in this experiment. $\mathrm{RH}$ strain kills all the mice inoculated within a week while Beverley strain often produces chronic infections in mice producing cysts in their brains.

1) When Beverley strain was inoculated into mice, proliferative forms first appear in the abdominal cavity 3 or 4 days after inoculation and the highest population was usually attained 7-11 days after inoculation. These proliferative forms diminished in number gradually thereafter. The longest duration of the presence was 18 days in one case. No essential difference was recognized between the normal and splenectomized mice in the period of appearance of the proliferative forms in the peritoneal fluid.

2) Shape and size of these proliferative forms showed no essential difference with those of the typical RH strain, only the breadth of the former being a little larger than the latter.

3) After the disappearance of the proliferative forms from the peritoneal fluid by the direct microscopical examinations, the peritoneal fluid of these mice was drawn repeatedly with different intervals and inoculated into clean mice. By these animal inoculations the peritoneal fluid proved to be infective until 33 days after inoculation. In one exceptional case the fluid drawn 78 days after inoculation produced cysts in mice inoculated. After the disappearance of the typical proliferative forms from these peritoneal fluid, smaller Toxoplasma-like bodies were often found by the microscopical examination. These small bodies may be the agent which produced infection in mice inoculated.

4) Mice inoculated with $\mathrm{RH}$ strain of Toxoplasma were treated with pyridazine (3-Sulfanilamido-6-methoxypyridazine). Survival period of these mice was prolonged: 38 of 142 mice survived up to 3 weeks or more after inoculation. Proliferative forms appeared in the peritoneal fluid 2 days after inoculation and disappeared mostly within 11 days, with an exceptional case in which they were first seen on the 11th day and disappeared on the 15th day.

5) These proliferative forms found in the pyridazine-treated mice were much larger in breadth than the normal proliferative forms of the same strain.

6) Mice which survived the RH infection for more than 20 days were examined for the presence of cyst. Among 26 of these mice 13 were found to 
have had cysts in their brains. Brain emulsions of these mice, regardless whether they were positive or negative of cysts by the microscopical examinations, all produced acute infections when inoculated into clean mice. All of these mice succumbed to the acute infection.

\section{REFERENCES}

1. Beverley, J. K. A.: A rational approach to the treatment of toxoplasmic uveitis. Trans. Opth. Soc., 68: 109-121, 1958.

2. Eyles, D. E.: The present status of the chemotherapy of Toxoplasmosis. Am. Jour. Trop. Med. Hyg., 2: 429-444, 1953.

3. Eyles, D. E.: Newer knowledge of the chemotherapy of toxoplasmosis. Ann. N. Y. Acad. Sci., 64: 252-267, 1956.

4. Eyles, D. E. and Coleman, N.: Relationship of size of inoculum to time to death in mice infected with Toxoplasma gondii. Jour. Parasit., 42: 272-276, 1956.

5. Frenkel, J. K.: Effect of vaccination and sulfamide therapy on experimental toxoplasmosis. Feder. Proc., 11: 468-469, 1952.

6. Frenkel, J. K.: Host strain and treatment variation as factors in the pathogenesis of toxoplasmosis. Am. Jour. Trop. Med. Hyg., 2: 390-415, 1953.

7. Frenkel, J. K.: Pathogenesis of toxoplasmosis and of infections with organisms resembling Toxoplasma. Ann. N. Y. Acad. Sci., 64: 215-251, 1956.

8. Harboe, A. and Erichsen, S.: A comparative study of the length of the parasites of 4 strains of Toxoplasma gondii. Act. Path. Mic. Scand., 37: 31-41, 1955.

9. Jacobs, L.: The biology of Toxoplasma. Am. Jour. Trop. Med. Hyg., 2: 365-389, 1953.

10. Jacobs, L.: Propagation, morphology and biology of Toxoplasma. Ann. N. Y. Acad. Sci., 64: 154-179, 1956.

11. Jacobs, L., Remington, J. S. and Melton, M. L.: The resistance of the encysted form of Toxoplasma gondii. Jour. Parasit., 46: 911-921, 1960.

12. Lainson, R.: Toxoplasmosis in England. II. Variation factors in the pathogenesis of Toxoplasma infections: The sudden increase in virulence of a strain after passage in multi-mammate rats and canaries. Ann. Trop. Med. Parasit., 49: $397-416,1955$.

13. Laison, R.: Observations on the development and nature of pseudocyst. Trans. Roy. Soc. Trop. Med. Hyg., 52: 396-407, 1958.

14. Melton, M. L. and Jacobs, L.: Repeated enhancement in virulence of a strain of Toxoplasma by passage in mice. Jour. Parasit., 41 suppl.: 21-22, 1955.

15. Sabin, A. B.: Toxoplasmic encephalitis in children. Jour. Am. Med. Ass., 116: 801-807, 1941.

16. Weinman, D. and Berne, R.: Therapeutic cure of acute experimental toxoplasmosis. Jour. Am. Med. Ass., 124: 6-8, 1944.

17. Weinman, D.: Toxoplasma and toxoplasmosis. Ann. Rev. Mic., 6: 281-298, 1952. 